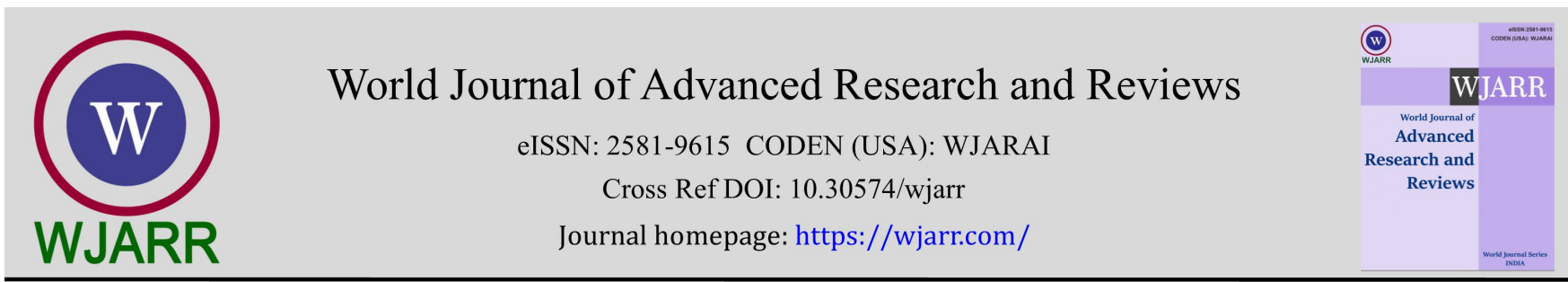

(RESEARCH ARTICLE)

\title{
Bacteriological investigation of meat sold in Ojo, Lagos, Nigeria
}

\author{
Dauphin Dighitoghi Moro* \\ Department of Microbiology, Lagos State University, P.M.B 0001, Ojo, Lagos, Nigeria.
}

World Journal of Advanced Research and Reviews, 2021, 10(01), 136-142

Publication history: Received on 27 February 2021; revised on 30 March 2021; accepted on 03 April 2021

Article DOI: https://doi.org/10.30574/wjarr.2021.10.1.0135

\begin{abstract}
Meat (beef) is one of the most widely consumed food products which is remarkably known for its high protein content, vitamins and desirable taste. Meat is consumed by all and sundry. However, the intrinsic properties of meat make it highly susceptible to changes usually brought about by an array of physical, chemical and biochemical attributes. Several bacterial species have been implicated in the spoilage of meat and it provides a good source of nutrients. One kilogram of meat samples purchased from ten retail points in different markets namely Okoko, Ojo, Iyana-Iba, Igbo-Elerin, Ajangbadi, Ikotun, Obadore, Akesan, Alaba and Volkswagen markets were investigated for microorganisms by standard methods. The meat samples were obtained in duplicates and cultured on MacConkey agar, Mannitol salt agar and nutrient agar. They were divided into two batches, the first batch was stored at the refrigerated temperature $\left(4{ }^{\circ} \mathrm{C}\right)$ while the second batch was at ambient temperature $27^{\circ} \mathrm{C} \pm 2{ }^{\circ} \mathrm{C}$ for 24 hours. The meat samples were enumerated bacteriologically using blender method. Ten grams of each sample was blended and introduced into buffered peptone water, homogenized and pre-incubated for $1 \mathrm{~h}$. Serial dilution was carried out and $0.1 \mathrm{ml}$ of serially diluted samples inoculated into the agar. Various bacterial species were isolated, identified culturally, morphologically and biochemically. For ambient temperature stored meat, the total viable count ranged from $1.3 \times 10^{4} \mathrm{cfu} / \mathrm{g}$ to $2.3 \times 10^{6}$ while refrigerated samples had counts which ranged from $1.3 \times 10^{4} \mathrm{cfu} / \mathrm{g}$ to $7 \times 10^{5} \mathrm{cfu} / \mathrm{g}$. In the unrefrigerated samples, total staphylococcal counts and total Enterobacteriaceae counts ranged from $1.3 \times 10^{3} \mathrm{cfu} / \mathrm{g}$ to $2.66 \mathrm{x} 10^{4} \mathrm{cfu} / \mathrm{g}$ and 1.2 $\mathrm{x} \mathrm{IO} \mathrm{IO}^{3}$ to $2.3 \times 10^{4} \mathrm{cfu} / \mathrm{g}$ respectively. Bacteria recovered include Staphylococcus aureus, Bacillus spp., Proteus spp., Micrococcus spp., Enterobacter spp., Leuconostoc spp., Klebsiella spp. and Pseudomonas spp., most of which are potentially spoilage bacteria as well as opportunistic pathogens. Several bacterial species isolated from refrigerated and unrefrigerated samples were similar, but the refrigerated meat appear to be safer as they had lower microbial load. Meat constitutes a risk factor which is minimized by careful handling, high personal hygiene and massive awareness campaign which may likely be heightened by consumption of raw or improperly cooked meat.
\end{abstract}

Keywords: Meat; Deteriorative changes; Contamination; Total Viable count; Opportunistic pathogens.

\section{Introduction}

Food can be obtained from plant and animal sources, with the latter being the principal source of protein. Food obtained from animal sources is usually perishable owing to the onset of enzymatic activities immediately after harvesting or slaughtering the animal [1]. Their inherent microbiota may also commence degradative changes thereby leading to short shelf-life of the product thus rendering it unfit for human consumption [2].

Beef is the most widely consumed food product as it is remarkably known for its high protein, vitamins, and desirable taste, so it is consumed by all and sundry [3].

\footnotetext{
* Corresponding author: Dauphin Dighitoghi Moro

Department of Microbiology, Lagos State University, P.M.B 0001, Ojo, Lagos, Nigeria.

Copyright (C) 2021 Author(s) retain the copyright of this article. This article is published under the terms of the Creative Commons Attribution Liscense 4.0.
} 
The intrinsic properties of meat makes it highly susceptible to deteriorative changes brought about by an array of physical, chemical and biological factors.

Microorganisms especially bacteria have been particularly recognized as perhaps one of the most important spoilage agents of meat [4]. Bacteria are seen as the singular most important agents capable of causing spoilage of meat, which is enhanced by a number of intrinsic and extrinsic factors during slaughtering, processing, and storage [5]. Meat is prone to contamination at various stages from primary production to when it is ready for consumption, and thus serves as a major source of food-borne illness and death usually from ingestion [6, 7].

The biochemical composition of meat also makes it prone to microbial attack. Meat also serves as an excellent substrate for the growth of hazardous microorganisms that cause infections in humans. This microbial post-mortem changes is particularly important because it could cause infections in human, deterioration in meat and subsequently economic losses to retailers [5].

In Nigeria, most especially within the metropolis, storage of meat within 24 hours is very questionable as meat are displayed on counters that usually fall far below hygienic standard [4].

Meat spoilage occurs due to the actions of a complex of interacting microorganisms. It is noteworthy that prior to microbial spoilage, meat typically undergoes autolytic changes that is rigor mortis and lipid oxidation collectively referred to as enzymatic changes [8]. The important factors responsible for meat deterioration include inherent microbes, temperature and meat surface area [9].

Various bacteria associated with meat spoilage have also been implicated in food infection and food intoxication particularly the enteric bacteria and Staphylococcus aureus.

This study aims at examining the bacteriological quality of fresh meat. The objectives includes determination of total aerobic plate count of bacteria, total Enterobacteriaceae count, total Staphylococci plate count as well as identification, characterization and enumeration of bacteria in fresh meat sold in the Lagos metropolis.

\section{Material and methods}

\subsection{Sample collection}

One kilogram of meat samples were purchased from ten points in different markets: Okoko, Ojo, Iyana-Iba, Igbo-Elerin, Ajangbadi, Ikotun, Obadore, Akesan, Alaba and Volkswagen markets.

They were classified into ten categories. The meat samples were obtained in duplicates. The meat were aseptically collected into Ziploc bags from the meat retailers and transported to the laboratory under sterile ice pack within 1 hour.

\subsection{Sample analysis}

Each of the duplicate samples was divided into 2 batches, the first batch was stored at ambient temperature $\left(27^{\circ} \mathrm{C}+2^{\circ} \mathrm{C}\right)$ while the second batch was stored at refrigerated temperature $\left(4^{\circ} \mathrm{C}\right)$. The duration of storage was 24 hours and they were subsequently examined.

The meat samples were bacteriologically enumerated using the blending method.

About $10 \mathrm{~g}$ of each sample was blended and introduced into $90 \mathrm{ml}$ of sterile peptone water. It was thereafter homogenized and pre-incubated for 1 hour. Serial dilution was carried out on all pre-incubated samples. About $0.1 \mathrm{ml}$ of the serially diluted samples was inoculated into freshly prepared agar plates using spread plate technique on nutrient agar (NA), McConkey agar (MCA) and mannitol salt agar (MSA). The inoculated plates were incubated at $27^{\circ} \mathrm{C}+2^{\circ} \mathrm{C}$ for 18 to 36 hours. A loopful from the first diluted sample was streaked on MCA and MSA. Culture plates with viable colonies were enumerated as follows:

Colony forming unit (CFU)/g = number of colonies/volume plated $\mathrm{x}$ dilution factors

All visible colonies from each agar plate were sub-cultured in their respective culture media until pure cultures were obtained. Pure cultures were preserved on agar slants for identification and characterization. 
Cultural characterization was based on morphology (shape), texture, pigmentation, margin and elevation on culture plates. A microscopic observation was based on Gram's reaction, cell shape and arrangement. Further biochemical characterization was based on the reaction to the following test: reaction on Kligler's iron agar, reaction on motility indole urea test, catalase test, oxidase test, coagulase test, citrate test, and sugar fermentation test.

\section{Results}

The results of the study of meat samples from the ten different sample points are as reported below. The total viable count (TVC) for meat stored at ambient temperature ranged from $1.3 \times 10^{4} \mathrm{cfu} / \mathrm{g}$ to $2.3 \times 10^{6} \mathrm{cfu} / \mathrm{g}$ while the count for refrigerated meat samples ranged from $1.3 \times 10^{4} \mathrm{cfu} / \mathrm{g}$ to $1.5 \times 10^{5}$ (Figure 1). In the unrefrigerated sample, the total Staphylococcal count (TSC) and total Enterobacteriaceae count (TEC) ranged from $2.4 \times 10^{4} \mathrm{cfu} / \mathrm{g}$ to $1.7 \times 10^{5}$ and $2.7 \times$ $10^{4} \mathrm{cfu} / \mathrm{g}$ to $7.2 \times 10^{5} \mathrm{cfu} / \mathrm{g}$ respectively as shown in figure 2 .

Figure 3 shows the total staphylococcal and total Enterobacteriaceae counts for the refrigerated sample which ranged from $1.3 \times 10^{3}$ to $2.6 \times 10^{4} \mathrm{cfu} / \mathrm{g}$ and $1.2 \times 10^{3}$ to $2.3 \times 10^{4} \mathrm{cfu} / \mathrm{g}$ respectively.

The bacteria isolated from the meat samples include Staphylococcus aureus, Bacillus spp., Proteus spp., Micrococcus spp., Enterobacter spp., Klebsiella spp., Pseudomonas spp and Leuconostoc spp. All the bacteria were isolated from both unrefrigerated and refrigerated meat. A total of 76 bacterial isolates were recovered from the meat samples and they were both Gram's negative and Gram's positive [Figure 4].

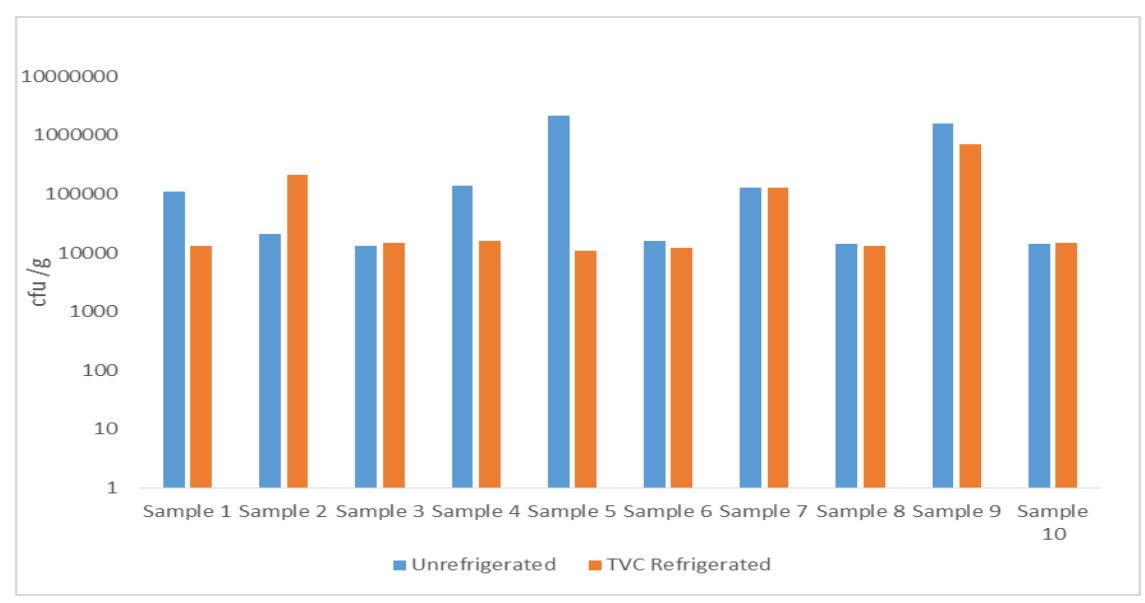

Figure 1 Total Viable count in Ambient and Refrigerated temperatures.

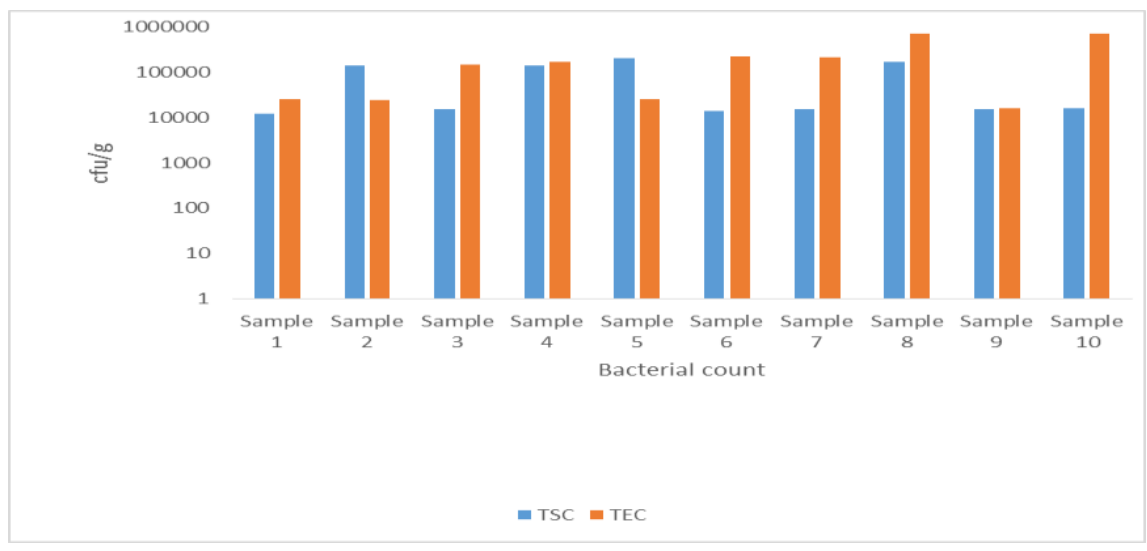

Figure 2 TSC and TEC Refrigerated Meat 


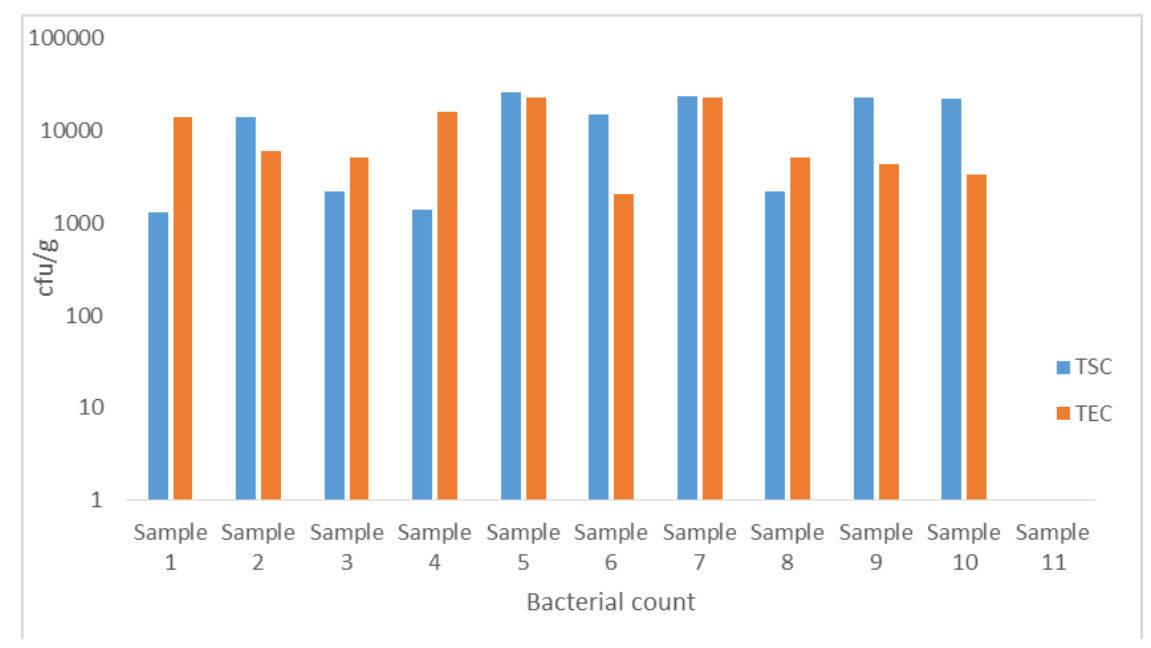

Figure 3 Total Staphylococcal and Enterobacteraceae Counts (Ambient tenperature\}.

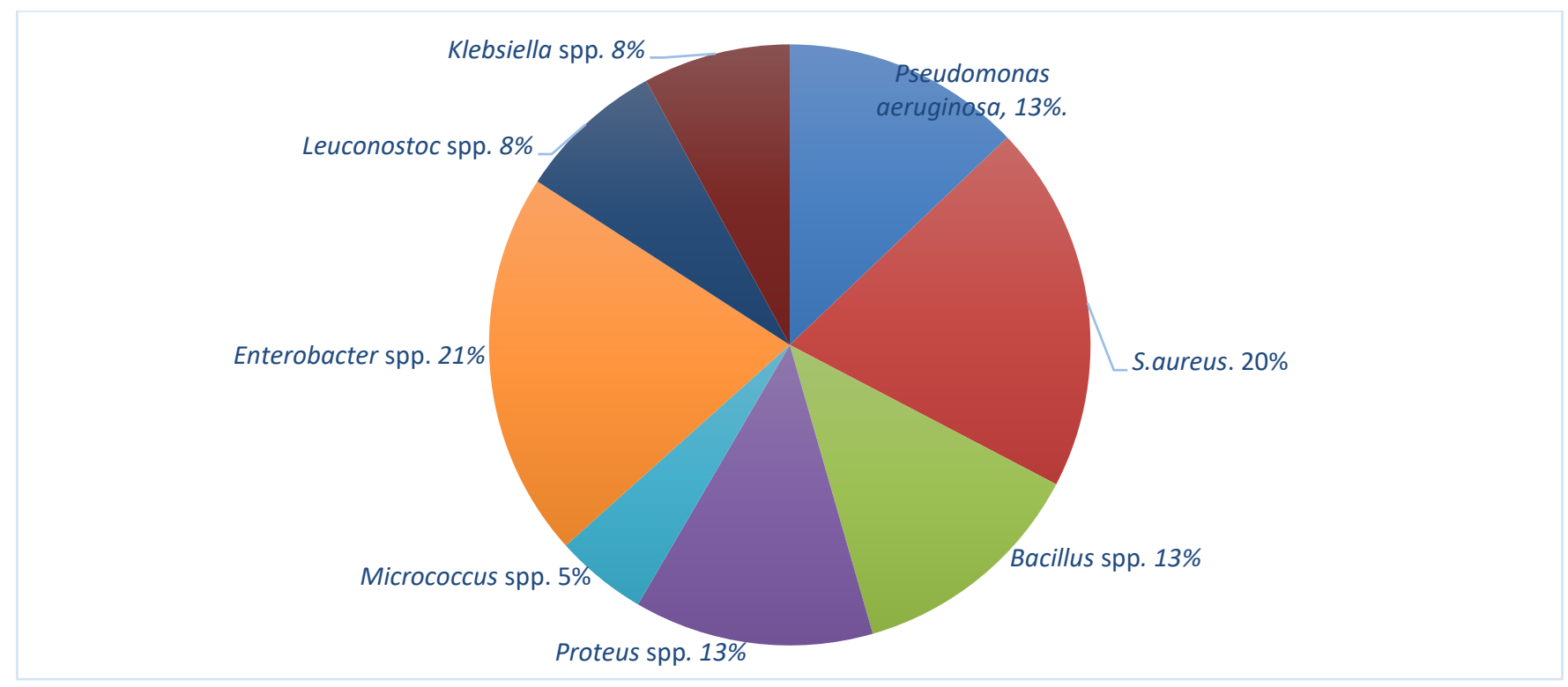

Figure 4 Frequency of bacteria isolated from meat

\section{Discussion}

Meat is perhaps one of the most perishable goods as a result of its inherent microflora, processing conditions as well as storage conditions [11].

In this study, all the meat samples yielded high bacterial counts, indicating that the meat contains a complex of interacting bacteria that could mediate spoilage. This agrees with report by Kalalou et al (8) that meat serves as an excellent substrate for the proliferation of microorganisms. Therefore, spoilage may progress uncontrollably in improperly handled meat especially because such meat serves as a source of nutrient to microorganisms.

The high incidence of aerobic bacteria is evident from the high amount of total viable count obtained from meat stored at ambient temperature thus indicates that the meat samples may be most likely unsuitable for consumption after 24 hours. According to Kuma [10], aerobic plate counts greater than $3.0 \times 10^{5} \mathrm{cfu} / \mathrm{g}$ on meat samples indicates spoilage. Conversely, meat stored at refrigerated temperature had aerobic plate counts of bacteria lower than the spoilage specification [10]. This implies that meat samples stored at refrigerated temperature can still be fit for consumption after 24 hours of storage. Therefore, refrigeration increases the shelf life of meat. Aerobic plate count is used to indicate 
the level of bacterial contamination and thus also used for monitoring food safety, hence it is important to ensure that foods sold are safe and wholesome under good hygienic conditions [12].

Water can be a source of meat contamination during washing, so water used in cleaning meat and meat processing must be of microbial contamination. Consequently, adequate supply of potable water which is analyzed frequently should be provided (6). Even when this study aimed at major microbial contaminants like S. aureus, E. coli and salmonellae, Proteus spp., Klebsiella spp., Micrococcus spp., Leuconostoc spp., and Shigella spp. were also identified concurrently on the meat samples. Similar bacterial contaminants have been reported by different workers on food, water and environmental samples [13].

The recovery of S. aureus, from the meat samples is an indication of improper handling of meat. According to Okonkwo et al [1], Iroha et al [4], the presence of Staphylococcus spp. on raw meat is a consequence of cross contamination from meat handlers, their clothes as well as processing equipment to the raw meat. The ubiquity of Staphylococcus spp. lends more support or credence to this. A high incidence of Staphylococcus spp. may affect taste, smell, and physical appearance of the meat. Staphylococcus aureus is an important food poisoning agent. In addition, some strains of Staphylococcus aureus produce enterotoxin. Staphylococcal enterotoxin is heat stable and can withstand boiling for thirty minutes. Ingestion of this toxin may cause sudden onset of illness within 3 to 4 hours, which is often characterized by nausea, vomiting and diarrhea [1]. Staphylococcal food poisoning may be rampant among meat consumers in the study area.

Majority of the bacterial isolates belong to the family Enterobacteriaceae which is also of high significance. Ercolini $e t$ al [11] reported that organisms of the family Enterobacteriaceae are responsible for slime production on meat stored at temperatures as low as $10^{\circ} \mathrm{C}$. Staphylococci also produce sulphides and malodorous amines as by-products from glucose and glucose-6-sulphate present in the meat [4]. Similar results on chicken products were reported by Marwan [12] and Fahim [15]

Enterobacter spp., Proteus spp., Klebsiella spp. and Pseudomonas aeruginosa were isolated from this study. This agrees with report by Javad et al [16] that these organisms are frequent colonizer of improperly handed food products and that their presence on meat can be as a result of cross contamination from the animals' intestine, hides and abattoir environment [16]. The high occurrence of Enterobacter spp., which are indicators of fecal contamination further confirms the high level of meat contamination [6,17]. Pseudomonas aeruginosa is mainly responsible for discoloration of meat, slime formation, pigmentation and production of malodour on meat. Proteus spp., Enterobacter spp., and Klebsiella spp. have variously been implicated in gastroenteritis [17]

In the same vein, the isolation of a lactic acid (homotactive) bacterium, Leuconostoc spp. which are homo-fermentative indicates that lactic acid bacteria are spoilage agents of food including meat [19]. Birhanu [19] reported that highly proteinous food are often contaminated with lactic acid bacteria, which particularly lead to green coloration of meat like Pseudomonas aeruginosa, formation of gas bubbles with meat issues as well as production of exopolysaccharides slimes on meat. Hygiene problems are not limited to slaughtering houses but also associated with incorrect processing and marketing practices $(6,17)$. Muinde $[20]$ reported that handling of food with bare hands may also result in cross contamination which agrees with this study. It was observed that there was no clear division of the slaughtering process as well as preventive mechanisms against infestation by rodents and insects in the abattoir, which corroborates report by Bersisa [6] and Haileselassie \{21]. Butchers' shops were observed to have poor hygienic conditions concerning cleaning of their shops, a finding which agrees with Ali [22].

The following recommendations are therefore made: 1 . Butchers should always wear protective overalls which are light in color or hair cover at all times while handling meat, 2 . Wearing of jewelry, wrist watches and other detachable items should be discouraged, 3.New applicants should be clinically and bacteriologically examined before employment at regular intervals, 4. Regular cleaning and disinfection of the beef retail outlets are required so as to reduce, minimize or completely eliminate meat contamination and 5. Massive awareness campaign on hygiene and sanitation in both abattoir and butchers' shops as well as development and application of appropriate control measures are needed to minimize meat contamination.

\section{Conclusion}

Several bacterial species isolated from the refrigerated and unrefrigerated meat samples were similar but the refrigerated had relatively lower microbial load. Meat constitutes a major risk factor which is minimized by refrigeration but may be heightened especially when such meats are consumed raw or partially cooked. Meat contamination begins from the abattoir to the butchers' shop where meat is further contaminated before it gets to the final consumers. The 
high microbial load in abattoir and butchers' shops is of serious public health significance thus requires special attention in order to ensure compliance with public health guidelines on food safety standards.

\section{Compliance with ethical standards}

\section{Acknowledgments}

The author would like to thank all abattoir workers and butchers for their cooperation and support in the execution of this study. The laboratory staff in the Department of Microbiology, Lagos State University, Lagos, Nigeria., who were very helpful in the preparation and analysis during this work hence, they are greatly appreciated. The duo of Mr. Baite Fukpene and Usuah Chinedu Emmanuel provided very impressive secretarial assistance.

\section{References}

[1] Okonkwo IO, Ogumusi TA, Ogubjobi AA, et al. Microbial studies on frozen during processed in Ibadan and Lagos, Nigeria. Scientific research and essay. 2008; 3(11): 537-546.

[2] Yousuf, AHM, Ahmed MK, Yeasmin S, Ahsan N, Rahman MM, Islam MM. Prevalence of microbial load in shrimp, panaeus monodon and prawn. World J. Agric. Sci. 2008; 4: 852-855.

[3] Iroha IR, Ugbo I, lang DC. Bacteria contamination of raw meat sold in Abakaliki, Ebonyi state Nigeria. Journal of Public Health and Epidemiology. 2011; 3(2): 49-53.

[4] Kim JW, Rajagopul SN. Antimicrobial activities of lactobacillus crospactus ATCC 33820 and lactobacillus gasseri ATCC33323. Journal of microbiology. 2001; 39: 146-148.

[5] Bersisa A, Dereje T, Chaluma N. Investigation of Bacteriological quality of meat from abbatoir and butchers shop in bishoftu, Central Ethiopia. Hindawi Int. J. Of Microbiology. 2019.

[6] Okonko I, Ikpoh I, Nkang A. Assessment of bacteriological quality of fresh Meats sold in Calabar Metropolis, Nigeria," Electronic Journal of Environmental, Agricultural and Food Chemistry. 2010; 9(1): 89-100.

[7] Kalalou I, Faid M, Ahami AT. Extending the shelf life of fresh minced camel meat at ambient temperature by Lactobacillus delbreuckii subsp. Delbreuckii. Journal of food production. 2004; 37: 11-16.

[8] Talon R, Walter D, Montel MC. Growth and Effect of staphylococci and lactic acid bacteria on unsaturated free fatty acids. Meat Sci. 2000; 54: 41-47.

[9] Kuma P, Rao ST, Harbabu Y, Manjunath D. Microbiological Quality Of Meat Collected From Municipal Slaughter Homes And Retail Meat Shop From Hyderabad, Karnataka Region India. 2014; 8: 364-369.

[10] Ercolini D, Federica Torrieri, E. et al. Changes in spoilage-related microbiota of beef during refrigerated storage under different packaging conditions. Appl. Environ. Microbiol. 2009; 72: 4663-4671.

[11] Marwan HAI. Sanitary Status Of Meat Meals At Hospitals Level In Kaluba Governorate, M.V. Sci Thesis(Mear Hygiene) Fac. Vet Med Bema Univ Egypt. Ssps V16. 2016.

[12] WHO, Food safety and food borne illness. Fact Sheet 237. WHO Geneva Switzerland. 2007.

[13] Endale B, Henlay G. Assessment of Bacteriological Quality of Meat Contact Surfaces In Selected Butcher Shop Of Melelle City Ethiopia. J. Enviromental and Occupational Science. 2013; 2(2): 61-66.

[14] Fahim AS, Dina IE, Lamiaa ML, Hala FE. Bacteriological status of chicken meat packaged at Menofia Governorate. Benha Vet. Med. J. 2018; 34(1): 28-40.

[15] Javad A, Safarmashaie S. Microbial profile of marketed broiler meat. Middle-East J. of Sci. Research. 2011; 9(5): 652-656.

[16] Akano 0, Moro DD, Deji-Agboola AM, et al. Public health implication of listeria species and other bacteria isolates of abattoir effluent in Lagos Nigeria, international research journal of microbiology. 2013; 4(7): 162-167.

[17] Ferrocino I. Study of spoilage microbial populations of beef during chilled storage by vacuum and nisin activated packaging. 14th workshopon the developments in the Italian PhD Research on Food science Technology and biotechnology. 2009; (16)18: 1-4. 
[18] Birhanu WS, Weldegebriel G. Assessment of microbiological quality and meat handling practices in butcher shops and abattoir found in Gondar town, Ethiopia," International Journal of Microbiological Research. 2007; (8): 5968.

[19] Muinde and Kuria Hygienic and Sanitary Practices Of Street Foods In Nairobi3, Kenya. Afr. J. Food \& Agric Nutr Development. 2005; 5: 1-5.

[20] Haileselassie M, Taddele H, Adhana K, Kalayou S. Food safety knowledge and practices of abattoir and butchery shops and the microbial profile of meat in Mekelle city, Ethiopia. Asian Pacific Journal of Tropical Biomedicine, 2013; (3)5: 407-412.

[21] Ali F. Microbial Contamination of Raw Meat and Its Environment In Retail Shops In Karachi, Pakistan. Journal of Infection In Developing Countries. 2010; 4(6): 382-388. 